\title{
Assessment of the Role of DNA Damage and Repair in the Survival of Primary Cultures of Rat Cutaneous Keratinocytes Exposed to Bis(2-chloroethyl)sulfide ${ }^{1}$
}

\author{
P. L. RIBEIRO, ${ }^{*}$ R. S. MITRA, ${ }^{*}$ AND I. A. BERNSTEIN ${ }^{* \dagger, 2}$ \\ *Toxicology Program, Department of Environmental and Industrial Health, and $\dagger$ Department of \\ Biological Chemistry. University of Michigan, Ann Arbor, Michigan 48109-2029
}

Received March 1, 1991: accepted August 5. 1991

\begin{abstract}
Assessment of the Role of DNA Damage and Repair in the Survival of Primary Cultures of Rat Cutaneous Keratinocytes Exposed to Bis(2-chloroethyl)sulfide. RiBeiro, P. L., MITRA, R. S., and Bernstein, I. A. (1991). Toxicol. Appl. Pharmacol 111, 342-351. Toxicity manifests itself as vesication in human skin exposed topically to bis(2-chloroethyl)sulfide (BCES). The destruction of the proliferating population of epidermal cells is a major component of the pathogenic process. A vailable data strongly suggest that damage to cellular DNA is a critical factor in the loss of these cells. However, the influence of DNA repair on this toxic response has not been adequately studied. Therefore, a study was undertaken to ascertain the influence of DNA repair on the survival of primary monolayer cultures of rat cutaneous keratinocytes exposed to BCES. The sensitive nucleoid sedimentation assay was employed for the determination of DNA damage in cultures exposed to very low levels of BCES. Initial experiments demonstrated that within $1 \mathrm{hr}$ of exposure to as little as $0.1 \mu \mathrm{M}$ BCES the structural integrity of cellular DNA was compromised. presumably resulting from the appearance of single-strand breaks in the nucleic acid. This same effect was demonstrated in basal cells derived from a stratified, cornified culture grown at the airliquid interface and exposed topically to the vesicant. Further studies with the monolayer culture demonstrated that the gross structural integrity of the DNA in cells exposed to as much as $5 \mu \mathrm{M}$ BCES was completely restored within the first $22 \mathrm{hr}$ following the exposure. However, this repair process appeared to be inefficient since a depression of thymidine incorporation into DNA and a significant loss of DNA were exhibitcd in cxposed cultures as long as $72 \mathrm{hr}$ after the initial

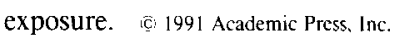

Bis(2-chloroethyl)sulfide (BCES) is a highly reactive bifunctional alkylating agent that produces a vesicant response in topically cxposed human skin (Warthin and Weller, 1919; Sinclair, 1949). The pathogenesis of this type

\footnotetext{
${ }^{1}$ This investigation was supported in part by NIH Training Grant ES07062 and by the USARMDC Contract DAMD17-86-C6124. The views, opinions, and findings contained in this report are those of the authors and should not be construed as the position, policy, or decision of the agencies supporting the research.

${ }^{2}$ To whom correspondence and reprint requests should be addressed at Department of Environmental and Industrial Health, 1528 Public Health I, University of Michigan, Ann Arbor, MI 48109-2029.
}

of skin lesion, in vivo, is quite complex, involving not only the epidermis but dermal and systemic components as well (Vogt et al., 1984). Topical exposure to a vesicating dose of BCES initially results in the selective destruction of the epidermal basal and lower spinous cell layers with little obvious effect on the upper differentiated layers, suggesting that the proliferating population of cells is the most sensitive epidermal cell type to BCES-induced cutaneous injury (Warthin and Weller, 1919; Sinclair, 1949; Papirmeister et al., 1985). These observations were especially significant since the basal layer is the site of DNA repli- 
cation, cell division, and commitment to differentiation, three of the most critical events in epidermal physiology (Vaughan and Bernstein, 1976).

The mechanism of vesication has remained elusive although much effort has been devoted to the elucidation of the possible cellular and molecular mechanisms responsible for the variety of BCES-induced responses in biological systems (Papirmeister et al., 1985). Exposure to a low level of BCES has been demonstrated to result in a depression of DNA synthesis in bacteria (Lawley and Brookes, 1965; Papirmeister and Davidson, 1965) and mammalian cells (Crathorn and Roberts, 1968; Roberts et al., 1968; Walker and Thatcher, 1968).

BCES belongs to a class of agents which readily alkylate cellular DNA, RNA, and protein (Ross, 1962; Wheeler, 1962). DNA appears to be a critical target and alkylation of the nucleic acid is an early molecular event for BCES-induced toxicity (Roberts, 1978; Fox and Scott, 1980; Papirmeister et al., 1985). In monolayer and in stratified, cornified cultures of keratinocytes, depression of DNA synthesis occurs after a lower level of exposure and sooner than inhibition of RNA or protein synthesis (Ribeiro, 1988; Vaughan et al., 1988). Cells are most sensitive to the toxic effects of the mustard just prior to their passage into the $\mathrm{S}$ (i.e., DNA synthetic) phase of the cell cycle (Roberts et al., 1968; Walker, 1966). Although numerous studies have provided data on the initial reaction between BCES and DNA, the available information concerning the repair of BCES-induced DNA damage and its role in maintaining cell survival is incomplete as well as contradictory.

As part of an effort to identify the cellular and molecular mechanisms of BCES-induced pathogenesis in human skin, the present study was undertaken to determine the role of DNA damage and repair in the survival of exposed primary cultures of rat cutaneous keratinocytes. The results obtained to date indicate that there is a loss of structural integrity in the DNA of monolayer cultures and stratified cultures exposed to BCES. Although cells exposed to low levels of BCES are capable of completely restoring the gross structural integrity of the DNA within the first $22 \mathrm{hr}$ following exposure, synthesis of the nucleic acid was depressed and the content of DNA in the culture was decreased during the subsequent $48 \mathrm{hr}$.

\section{MATERIALS AND METHODS}

\section{Cell Culture}

Low calcium monolayer cultures. A mixed population of proliferative and differentiated cutaneous keratinocytes was isolated from the dorsal skin of newborn CFN (Carworth Farms, NY) albino rats as described by $\mathrm{Ku}$ and Bernstein (1988a). The keratinocytes were fractionated on a continuous gradient formed by centrifugation of $38 \%$ Percoll at $30,000 \mathrm{~g}$ for $15 \mathrm{~min}$ at $4^{\circ} \mathrm{C}$ (Ribeiro, 1988). The gradients were calibrated by running a parallel gradient containing density marker beads (Pharmacia/PL Biochemicals. Piscataway, NJ). Under these conditions, the keratinocytes separated into two distinct bands of cells. In the upper band, corresponding to a density of $1.049 \mathrm{~g} / \mathrm{cc}$. about $90 \%$ of the cells were at various stages of differentiation and $10 \%$ of the cells were basal. Cell debris was also present in this band. The lower, most dense band of cells, found at a density of $>1.075 \mathrm{~g} / \mathrm{cc}$, consisted of $>95 \%$ basal cells by the criteria of the same density and morphology as the basal cells isolated from the epidermis. By the criterion of the incorporation of $\left[{ }^{3} \mathrm{H}\right]$ thymidine during replicative DNA synthesis, Ribeiro (1988) confirmed that these cells were of the basal cell type. This fraction of cells was collected, washed with phosphate-buffered saline, and resuspended in low calcium growth medium [i.e., a medium having $0.08 \mathrm{mM} \mathrm{Ca}^{2+}$ and made from calcium-free Eagle's minimal essential medium (MEM) supplemented with $10 \%$ Chelex-treated fetal bovine serum (FBS) (Brennan et al., 1975), $10 \mu \mathrm{g} / \mathrm{ml}$ insulin, $10 \mu \mathrm{g} / \mathrm{ml}$ hydrocortisone, $100 \mathrm{IU} / \mathrm{ml}$ penicillin, $100 \mu \mathrm{g} / \mathrm{ml}$ streptomycin, and $1.0 \mu \mathrm{g} / \mathrm{ml}$ Fungizone (Vaughan et al. 1981) and calcium chloride to a final concentration of $0.08 \mathrm{~mm}$ ]. Corning plastic $100-\mathrm{mm}$ culture dishes were inoculated at a cell density of $2.6 \times 10^{5}$ cells $/ \mathrm{cm}^{2}$. Cultures were maintained at $35^{\circ} \mathrm{C}$ in a humidified $5 \% \mathrm{CO}_{2} /$ air atmosphere with the medium being changed every other day,

When grown under such conditions of low calcium, cultures grew as a monolayer (Hennings et al., 1980; Hennings and Holbrook, 1983; Brown et al., 1987), achieving confluence after 2 days. After staining with lectins labeled with fluorescein isothiocyanate (Brabec et al., 1980), such cultures exhibit a pattern that is consistent with the presence of basal and early spinous cells (Brown et al, 1987; Ku and Bernstein, 1988a), the putatively sensitive cell types involved in BCES-induced vesication. 
Lifted membrane cultures. This system, developed by Vaughan et al. (1986) as a modification of the method of Lillie et al. (1980), consists of stratified, cornified cultures of keratinocytes grown on nylon microporous membranes at the air-liquid interface. Such "lifted" cultures exhibit many of the morphological as well as biochemical features of an intact epidermis (Bernstam et al., 1986).

To develop the lifted membrane culture, cells in the lower band of the Percoll gradient (cf. above), resuspended in complete growth medium [MEM containing $10 \%(\mathrm{v} /$ v) FBS and supplemented as described above], were seeded on sterile Puropor-200 nylon membranes (Cat. No. 66470, Gelman Sciences, Ann Arbor, MI) at a cell density of $1.2 \times 10^{5}$ cells $/ \mathrm{cm}^{2}$ in Corning 24-well culture plates. The cultures were grown initially submerged for 7 days and then at the air-medium interface for 14 days as described by Vaughan et al. (1986).

\section{Conditions for Exposure to BCES}

Low calcium monolayer cultures (20-24 hr old) were washed with phosphate-buffered saline $(\mathrm{pH} 7.2)$ containing $0.08 \mathrm{mM} \mathrm{CaCl}_{2}$ and $0.1 \mathrm{mM} \mathrm{MgCl}_{2}$ (low calcium phosphate-buffered saline). A series of dilutions were made from a stock solution of BCES $(10 \mathrm{mg} / \mathrm{ml}$ in methylene chloride, obtained from the USARMDC, Aberdeen Proving Grounds, MD) in prewarmed low calcium phosphatebuffered saline and applied to the cultures. In experiments involving methyl- $N^{\prime}$-nitro- $N$-nitrosoguanidine (MNNG), a stock solution of this toxicant was prepared fresh in absolute ethanol, diluted in low calcium phosphate-buffered saline, and applied to the cultures. Exposures were conducted for $1 \mathrm{hr}$ at $35^{\circ} \mathrm{C}$ in a humidified $5 \% \mathrm{CO}_{2} /$ air atmosphere. After the exposure to BCES (or MNNG), the cultures were washed with low calcium phosphate-buffered saline and either incubated further in fresh low calcium growth medium or harvested by centrifugation in the cold after exposure to $0.05 \%$ trypsin (w/v) (prepared in $\mathrm{Ca}^{2+}$ / $\mathrm{Mg}^{2+}$-free phosphate-buffered saline containing $0.02 \%$ EDTA). The cell pellets were kept on ice for later use.

In aqueous medium, BCES hydrolyzes to bis(2-hydroxyethyl)sulfide, $\mathrm{Cl}^{-}$, and $\mathrm{H}_{3} \mathrm{O}^{+}$in a reaction sequence of four steps that is dependent on temperature and has been described as a "quasimonomolecular process with first-order kinetics" (cf. Papirneister et al., 1991). The first and third steps are postulated to be reversible and to result in the formation of cyclic ethylene sulfonium ions which react with nucleophiles such as the nucleic acid bases. Since in these steps $\mathrm{Cl}^{-}$is liberated, the rate of hydrolysis is retarded in the presence of added $\mathrm{Cl}^{-}$. BCES has been found to have a half-life of about $25 \mathrm{~min}$ in phosphate-buffered saline at $37^{\circ} \mathrm{C}$ (unpublished data). A value of $24 \mathrm{~min}$ for the half-life of BCES in $0.142 \mathrm{M} \mathrm{NaCl}$ at $23.7^{\circ} \mathrm{C}$ has been reported (cf. Papirmeister et al., 1991). The levels of BCES given for exposure in each experiment should be understood to represent the initial concentration.
Lifted membrane cultures were exposed to BCES (in $70 \%$ dimethyl sulfoxide) according to the procedure described by Vaughan et al. (1988). After 1 to $2 \mathrm{hr}$ of topical exposure, the cultures were washed in Earle's balanced salts solution to remove any residual BCES. The cultures were next immersed in phosphate-buffered saline that was free of $\mathrm{Ca}^{2+}$ and $\mathrm{Mg}^{2+}$ for $15 \mathrm{~min}$ at $35^{\circ} \mathrm{C}$ which was followed by an incubation in the same medium containing trypsin for $20-25 \mathrm{~min}$ at $35^{\circ} \mathrm{C}$. The cultures were separated from the membranes as intact sheets which were then gently brushed with a camel hair brush to dislodge the loosened cells of the lower strata from the upper cornified cell layers. The resultant mixed cell suspension was filtered through a nylon mesh $(80 \mu \mathrm{m})$ and fractionated on a selfforming isotonic Percoll gradient as described above. The lower band was recovered and the basal cells were collected by centrifugation in the cold and kept on ice for later use.

A value for the half-life of $\mathrm{BCES}$ in $70 \%$ dimethyl sulfoxide is not available in the literature but is reported to be $2.6 \mathrm{~min}$ at $37^{\circ} \mathrm{C}$ in $\mathrm{H}_{2} \mathrm{O}$ (cf. Papirmeister et al., 1991).

\section{Nucleoid Sedimentation Assay for DNA Strand Breaks}

The nucleoid sedimentation assay was modified for its application to cultured epidermal cells. Continuous linear sucrose gradients $[15-30 \%(w / v)]$ containing Hoescht 33258 dye ( $1 \mu \mathrm{g} / \mathrm{ml}$; Fluka, Hauppauge, NY) were prepared in nitrocellulose ultracentrifuge tubes according to the method of Romagna et al. (1985). Polyallomer tubes (Sarstedt, Princeton, NJ) coated with polyvinyl alcohol (Holmquist, 1982) could be substituted for the nitrocellulose tubes. The gradients were overlayed with $0.3 \mathrm{ml}$ of lysis solution [2.35 $\mathrm{M} \mathrm{NaCl}, 11.7 \mathrm{mM}$ Tris- $\mathrm{HCl}, 11.7 \mathrm{mM}$ EDTA, $10 \mathrm{~mm}$ dithiothreitol, and $0.6 \%(\mathrm{v} / \mathrm{v})$ Triton X$100, \mathrm{pH} 8]$. The inclusion of dithiothreitol was necessary for the uniform lysis of the epidermal cells. The cell pellets were resuspended in ice-cold phosphate-buffered saline free of $\mathrm{Ca}^{2+}$ and $\mathrm{Mg}^{2+}$ to a final cell density of $1-2 \times 10^{7}$ cells/ $\mathrm{ml}$ and a $0.05-\mathrm{ml}$ aliquot was layered over the lysis solution. After a lysis period of $10-15 \mathrm{~m}$ in the dark at room temperature, the gradients were centrifuged in a Model L8 ultracentrifuge (Beckman Instruments, Arlington Heights, IL) at $85,000 \mathrm{~g}$ for $20-25 \mathrm{~min}$ in the SW 50.1 rotor at $20^{\circ} \mathrm{C}$. After the centrifugation, the nucleoid bands were visualized in the gradients by illumination of the DNAHoescht dye complex at long wavelength in the ultraviolet (366 nm, Mineralight, UV Products, San Gabriel, CA).

The sedimentation values for the nucleoid bands were calculated as the ratio of the distance traveled by the nucleoid to the total length of the gradients. According to the conditions described above, control nucleoid exhibited a sedimentation value of 0.70 . Results were expressed in percentages of control sedimentation.

The basal cells obtained from the lifted membrane cultures were processed for this assay in much the same manner as the cells derived from monolayer cultures, except that a slightly longer lysis time (15-20 min) was necessary. 
Determination of DNA and Incorporation of $\left[{ }^{3} H\right]$ Thymidine into the Acid-Precipitable Fraction

After the exposure to BCES, the low calcium cultures were washed several times with phosphate-buffered saline containing $\mathrm{Ca}^{2+}$ and $\mathrm{Mg}^{2+}$ and further incubated in fresh low calcium growth medium. At the appropriate times, the monolayer cultures were pulse-labeled with [methyl${ }^{3} \mathrm{H}$ ] thymidine (New England Nuclear, Boston, MA) for 1 hr at $35^{\circ} \mathrm{C}$. After this incubation, the cultures were placed on ice and treated with ice-cold trichloroacetic acid [TCA, $7 \%(\mathrm{w} / \mathrm{v})]$. The resulting precipitates were processed for the determination of DNA and acid-precipitable radioactivity according to the procedure of Setaro and Morley (1976). The TCA precipitates were dissolved in $0.1 \mathrm{~N}$ $\mathrm{NaOH}$ instead of $1 \mathrm{~N} \mathrm{KOH}$ (Abler and Bernstein, 1984). Aliquots $(0.1 \mathrm{ml})$ of each sample were used for the spectrophotofluorometric determination of DNA (Setaro and Morley, 1976). A second aliquot of each sample was transferred to a scintillation vial mixed with $5 \mathrm{ml}$ ACS (Amersham, Arlington Heights, IL) and counted in a Packard Tricarb liquid scintillation spectrometer. Acid-insoluble radioactivity was normalized to the amount of DNA that was present and expressed as percentage of control.

\section{Statistical Analysis}

Chi-squared $\left(\chi^{2}\right)$ analysis was performed on the MNNG treatment nucleoid sedimentation database, the thymidine incorporation database, and the DNA content database. The level of significance used for all of these evaluations was $p \leqslant 0.01$.

\section{RESULTS}

Validation Studies of the Nucleoid Sedimentation Assay

Cook and Brazell (1976a) demonstrated that nucleoid contains supercoiled domains as exhibited by a biphasic response to sedimentation in gradients containing increasing concentrations of ethidium bromide. Exposure to a DNA-damaging agent disturbs the structural integrity of the DNA, resulting in a loss of supercoiling as indicated by a decreased nucleoid sedimentation rate (in the absence of ethidium bromide). In order to determine whether epidermal cell nuclcoid cxhibited this behavior, a similar experiment was performed. The results (data not shown) demonstrated that nu- cleoid prepared from untreated monolayer cultures of keratinocytes still maintained structural integrity and supercoiled domains in the DNA as indicated by a biphasic response to increasing concentrations of ethidium bromide. These findings confirmed that the minor modifications introduced in the preparation of nucleoid from keratinocyte cultures did not alter the characteristics of the assay system.

In order to test the ability of the nucleoid assay to detect structural damage in the DNA of keratinocytes, a proven damaging agent for DNA was employed. MNNG is capable of producing single-strand breaks in the DNA (Gichner and Veleminsky, 1982) as well as a reduction in the sedimentation rates of nucleoid prepared from exposed colon carcinoma cells (Mattern et al., 1982). The carcinogen can also produce single-strand breaks in the DNA of keratinocyte cultures (Sorscher and Conolly, 1989).

Low calcium monolayer cultures were exposed to a range of concentrations $(0.5-50 \mu \mathrm{M})$ of MNNG for $1 \mathrm{hr}$, washed, and immediately processed for evaluation by the nucleoid sedimentation assay. The results (data not shown) indicated that a significant reduction $(0-50 \%)$ in the rate of sedimentation occurred over a narrow range of doses $(0-2.5 \mu \mathrm{M})$ of MNNG. As the dose increased beyond this point, only a small additional effect was observed.

\section{Demonstration That BCES Disturbs DNA Structural Integrity in Exposed Monolayer Cultures}

Monolayer cultures were exposed to a range of concentrations of BCES in order to determine whether BCES affected the structural integrity of cellular DNA. Immediately after a 1-hr exposure, the cultures were washed and processed for evaluation of the integrity of the DNA by the nucleoid sedimentation assay. A decrease in the rate of sedimentation was detected in the nucleoid of monolayer cultures exposed to as low as $0.1 \mu \mathrm{M}$ BCES (Fig. 1). The extent of structural damage, attributable 


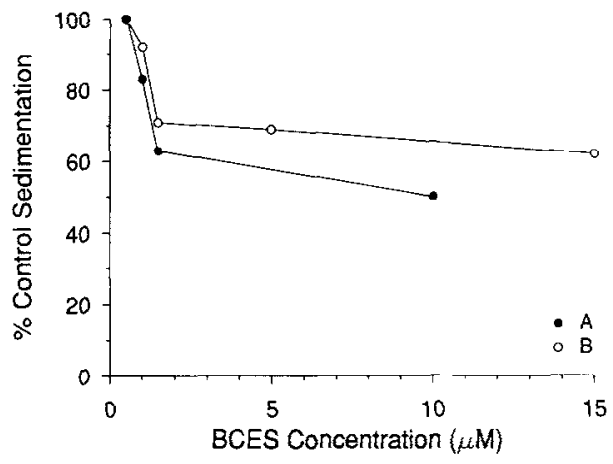

FIG. 1. Effect of BCES on nucleoid sedimentation: A dose response. Sedimentation of nucleoids prepared from low calcium monolayer cultures exposed to (A) 0,0.1, 1.0, and $10 \mu \mathrm{M}$ and (B) $0,0.5,5.0$, and $15 \mu \mathrm{M}$ BCES, respectively. All conditions were as described in the legend to Fig. 2. Each point represents the mean of two separate determinations.

to the exposure to BCES, increased in a concentration-dependent manner as the concentration was increased from 0 to $1.0 \mu \mathrm{M}$ BCES. As the concentration of BCES was increased from 1 to $10 \mu \mathrm{M}$ (Fig. 1, Experiment $\mathrm{A}$ ) and from 1 to $15 \mu \mathrm{M}$ (Fig. 1, Experiment B), only a small additional reduction in sedimentation was seen.

\section{Detection of DNA Damage in Basal Cells}

In a preliminary study, the nucleoid sedimentation assay was employed with the lifted membrane cultures in an effort to determine if a similar effect could also be demonstrated in the basal cells of a stratified and cornified culture after topical application of BCES. The results of several experiments are represented as a composite in Fig. 2. As indicated in the figure, loss of structural integrity of the DNA occurred in a dose-dependent manner in the DNA of basal cells derived from lifted membrane cultures topically exposed to BCES.

\section{At Low Doses, BCES-Induced Structural Damage in DNA Is Repaired}

In order to evaluate the cell's ability to repair BCES-induced structural damage to DNA, low calcium monolayer cultures were first exposed to $0-15 \mu \mathrm{M}$ BCES and then assayed at 0 and $22 \mathrm{hr}$ after exposure to determine if the cells had the capacity to repair such damage. As noted in Fig. 3, complete recovery was evident in cultures exposed to concentrations as high as $5 \mu \mathrm{M}$ BCES. At doses which exceeded this level, however, the recovery was not complete at $22 \mathrm{hr}$. These results suggest that at low concentrations the cells are capable of fully repairing the BCES-induced structural damage in the DNA. At higher concentrations, however, the damage may be so extensive that the cell's ability to repair damaged DNA is exceeded.

\section{Kinetics of the Repair of BCES-Induced Struc- tural Damage in DNA}

An experiment was designed to follow the fate of the BCES-induced structural damage in the DNA of monolayer cultures over the course of a 24-hr incubation following exposure. I ow calcium monolayer cultures were

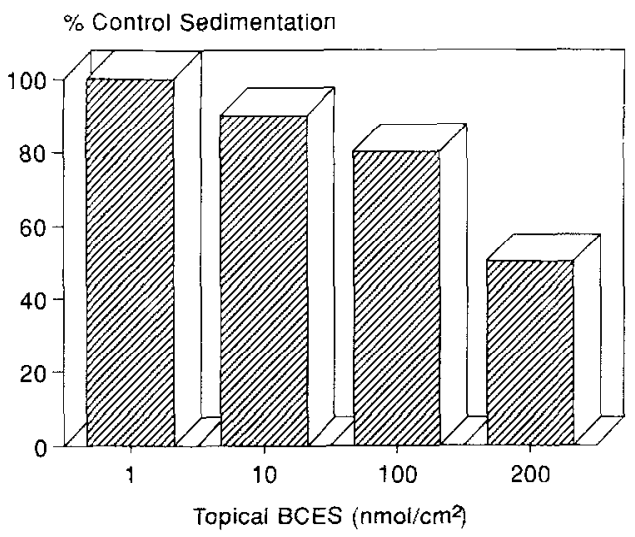

FIG. 2. Effect of BCES on the sedimentation of nucleoids from basal cells in exposed lifted membrane cultures. Lifted membrane cultures ( 14 days old) were exposed topically to $1,10,100$, or $200 \mathrm{nmol} \mathrm{BCES} / \mathrm{cm}^{2}$ for $1 \mathrm{hr}$ and washed. The cultures were then dispersed with trypsin/EDTA and the basal cells were isolated (see Materials and Methods). The nucleoid assay was performed with these cells according to the conditions described under Materials and Methods. Each point represents the average of two separate determinations. 


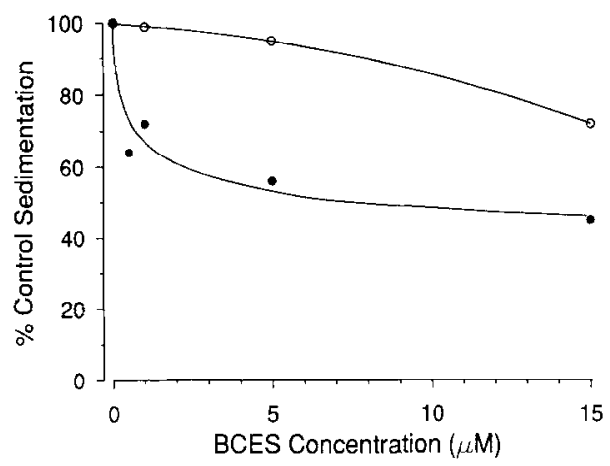

FIG. 3. Recovery of nucleoid sedimentation in low calcium monolayer cultures exposed to different concentrations of BCES. Sedimentation of nucleoids prepared from low calcium monolayer cultures exposed to $0,0.5,1.0$, 5.0 , and $15 \mu \mathrm{M}$ BCES, respectively, and assayed at $0(\bullet)$ and $22 \mathrm{hr}(\mathrm{O})$ after the initial exposure. All conditions were as described in the legend to Fig. 2. Each point represents the average of two separate determinations.

exposed to two different concentrations of BCES (2.4 and $4.8 \mu \mathrm{M}$, respectively) and assayed at several times throughout the 24-hr period. During this study (Fig. 4), the nucleoid sedimentation rates were initially reduced to 80 and $70 \%$ of the controls, respectively. Further decreases were evident in both dose groups when assayed at $7 \mathrm{hr}$. In the next $6 \mathrm{hr}$ of incubation, the sedimentation values for both groups increased and by $25 \mathrm{hr}$ after exposure the sedimentation rates were not significantly different from control.

Depression of the Incorporation of $\left[{ }^{3} H\right] T h y-$ midine into DNA and Loss of DNA in the Monolayer Culture following Exposure to $B C E S$

Low calcium monolayer cultures were monitored for the incorporation of $\left[{ }^{3} \mathrm{H}\right]$ thymidine and for total DNA during the 72 $\mathrm{hr}$ following exposure to BCES. The data in Fig. 5 show that at $24 \mathrm{hr}$ following exposure $\left[{ }^{3} \mathrm{H}\right]$ thymidine incorporation was depressed in a dose-dependent manner ranging from $47 \%$ at $0.625 \mu \mathrm{M}$ BCES to $87 \%$ at $10 \mu \mathrm{M}$ BCES. After $48 \mathrm{hr}$ of incubation, this inhibitory effect

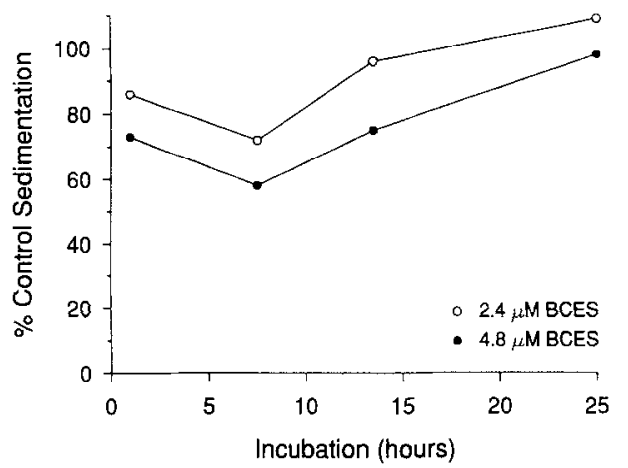

FIG. 4. Time course of the recovery of nucleoid sedimentation in the low calcium monolayer cultures exposed to BCES. Low calcium monolayer cultures were exposed to two different concentrations of BCES $(2.4$ and $4.8 \mu \mathrm{M}$ BCES) for $1 \mathrm{hr}$, washed, and incubated in fresh low calcium growth medium. The nucleoid sedimentation assay was performed on the exposed cells at $0,7,13$, and $24 \mathrm{hr}$ of incubation. Each point was the average of two separate determinations.

was even more pronounced at all doses. After $72 \mathrm{hr},\left[{ }^{3} \mathrm{H}\right]$ thymidine incorporation was maximally inhibited in cultures exposed to doses greater than 1.25 $\mu \mathrm{M}$ BCES. In cullures ex-

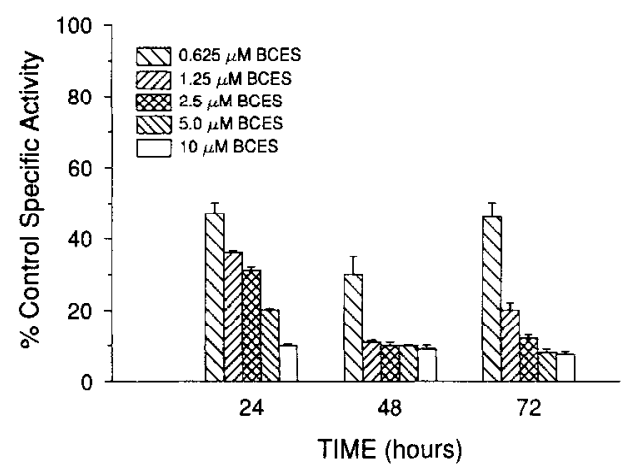

FIG. 5. Prolonged depression of thymidine incorporation in exposed low calcium monolayer cultures. Relative specific activity in low calcium monolayer cultures exposed to $0.625,1.25,2.5,5$, and $10 \mu \mathrm{M} \mathrm{BCES}$, respectively, for $1 \mathrm{hr}$, washed, and incubated in fresh low calcium growth medium. After the completion of 24,48 , and $72 \mathrm{hr}$ of incubation, the cultures were labeled with $\left[{ }^{3} \mathrm{H}\right] \mathrm{TdR}$ for 1 $\mathrm{hr}$ and were then processed for counting. Results were expressed as a percentage of the specific activity $(\mathrm{dpm} / \mu \mathrm{g}$ DNA) of control (untreated) cultures. Each point represents the mean of three separate determinations. 
posed to 0.625 and $1.25 \mu \mathrm{M}$ BCES, there appeared to be some degree of recovery as indicated by increases of 16 and $8 \%$, respectively, in the incorporation of $\left[{ }^{3} \mathrm{H}\right]$ thymidine.

As an indicator of lethality and loss of cells from the culture, total DNA was determined in cultures at 24 and $50 \mathrm{hr}$ following a $1-\mathrm{hr}$ exposure to 1,5 , or $15 \mu \mathrm{M} \mathrm{BCES}$. The results shown in Fig. 6 demonstrate that 10, 18, and $18 \%$, respectively, of the DNA was lost from the monolayers within the first $24 \mathrm{hr}$ after exposure. This effect became more pronounced at $50 \mathrm{hr}$ of incubation for the groups exposed to 5 and $15 \mu \mathrm{M}$ BCES (33 and $49 \%$ reduction, respectively). There was no change between 24 and $48 \mathrm{hr}$ in the total DNA in the group exposed to $1 \mu \mathrm{M}$ BCES.

\section{DISCUSSION}

The nucleoid sedimentation assay developed by Cook and Brazell (1976a) has been used as a sensitive assay for the study of DNA damage and its repair from exposure to irradiation (Cook and Brazell, 1976b; Yew and Johnson, 1979; Charles and Cleaver, 1982; Aldenhoff and Sperling, 1984), metals (Robison et al. . 1984), and alkylating agents (Mattern et al. 1982; Romagna et al., 1985). Nucleoid, consisting of supercoiled nuclear DNA and some associated protein, sediments in a $15-30 \%$ linear gradient of sucrose in a manner similar to that of intact supercoiled DNA (Cook et al., 1976). The presence of singlestrand breaks in the DNA results in a loss of supercoiled character in the nucleic acid and a consequent decrease in the sedimentation rate of nucleoid (cf. Cook and Brazell, 1976b; Robison et al., 1984). Although the nucleoid sedimentation assay has been used to quantify the number of single-strand breaks in DNA, it really measures the loss of supercoiling by any mechanism (Cook and Brazell, 1976a).

In the present investigation, nucleoid sedimented more slowly as the cells were exposed to higher levels of BCES. The assay was sufficiently sensitive to determine an effect in the

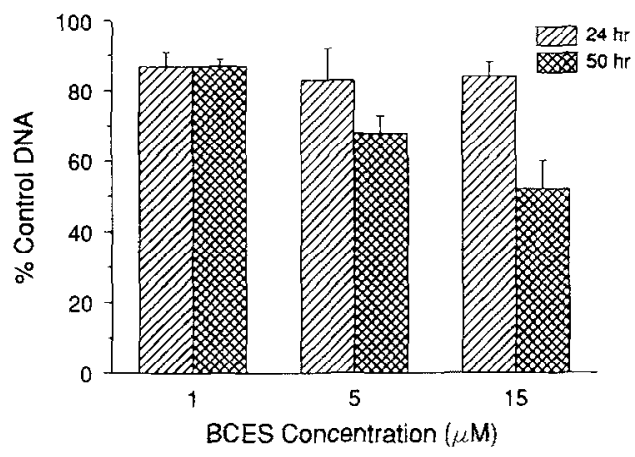

FIG. 6. Effect of BCES on the total DNA in exposed low calcium monolayer cultures. Low calcium monolayer cultures were exposed to 1,5 or $15 \mu \mathrm{M}$ BCES for $1 \mathrm{hr}$. Then the cultures were washed and incubated in fresh low calcium growth medium. At 24 and 50 hr of incubation, the cultures were processed for the fluorometric determination of total DNA. Results were expressed as a percentage of the control (untreated) cultures. Each point represents the mean of three separate determinations.

DNA of cultures within $1 \mathrm{hr}$ after exposure to as low as $0.1 \mu \mathrm{M}$ BCES. This effect was equated with the introduction of single-strand breaks in the DNA since single-strand breakage is known to occur during repair of alkylated DNA (Friedberg, 1985; Lindhal, 1982).

Cutaneous vesication from exposure to $\mathrm{BCES}$ in vivo involves the degeneration of the basal and lower spinous cells, leaving the upper cell layers as a cap for the blister. This degradative phenomenon has been mimicked in lifted membrane cultures of cutaneous keratinocytes derived from the rat (Scavarelli-Karantsavelos, 1989). By 2 days after BCES was applied topically at a level of $50 \mathrm{nmol} / \mathrm{cm}^{2}$. the basal cells of these cultures were completely destroyed without obvious effect on the differentiated cells. However, application of a dosage of $10 \mathrm{nmol} / \mathrm{cm}^{2}$ resulted in only foci of necrosis in the basal layer. Nevertheless, as noted in the present study, after an exposure of $10 \mathrm{nmol} / \mathrm{cm}^{2}$, there was a significant effect on the integrity of the DNA in the basal cell layer (Fig. 2). This was surprising since only a small fraction of the applied dose of BCES would be expected to reach the basal layer in as much as BCES alkylates protein and the 
cornified cells of the outer stratum of the culture are filled with keratin. However, Scavarelli-Karentsavelos et al. (1990) showed that within $15 \mathrm{~min}$ after the topical application of $\left[{ }^{14} \mathrm{C}\right] \mathrm{BCES}$ at $50 \mathrm{nmol} / \mathrm{cm}^{2}$, the mustard had penetrated as many as 20 layers of living and cornified cells, and radioactivity was present in the basal cells. It should be noted that after a topical exposure of $10 \mathrm{nmol} / \mathrm{cm}^{2}$, nucleoid derived from the differentiated cells had a sedimentation rate that was not significantly different from the control rate (Scavarelli-Karentsavelos, 1989).

In the final phase of the project, studies of the functional integrity of DNA in cultures exposed to BCES produced unexpected results. These studies demonstrated that, while cells were able to reconstitute the gross structural integrity of DNA (i.e., supercoiling) by $24 \mathrm{hr}$ after exposure to $5 \mu \mathrm{M}$ BCES, they still exhibited a significant decrement in physiology. The rate of DNA synthesis was still depressed by more than $90 \%$ at $48 \mathrm{hr}$ after exposure to BCES. Furthermore, the total DNA in cultures exposed to this level of BCES was reduced by $33 \%$ from control at $50 \mathrm{hr}$ after treatment. These data complement the report of $\mathrm{Ku}$ and Bernstein (1988b) that after exposure to $1 \mu \mathrm{M}$ $\mathrm{BCES}$, cells in low calcium monolayer cultures resumed replicative DNA synthesis only $48 \mathrm{hr}$ later but at a rate lower than control. This observed inhibition of DNA synthesis was accompanied by a decrease in the number of mitotic figures. Cultures exposed to $5 \mu \mathrm{M}$ BCES did not resume replicative DNA synthesis during a period of 6 days following exposure and the total number of cells in the culture was reduced to $<20 \%$ of control at the end of the experiment. In addition, the predominant cell in the culture after 6 days was a large, differentiated cell. It appears that despite the ability of the cells to repair the gross structure of their DNA, some type of damage remained such that the normal balance between epidermal cell proliferation and differentiation could not be reestablished.

There are at least two possible explanations for the residual toxicity in cells that show nu- cleoid sedimentation values at the control level. One possibility is that the observed repair process is error-prone (Cleaver, 1978; Alexander, 1969) and results in informational crrors in the DNA. Fan and Bernstein (1991) have shown that African monkey kidney cells exposed to $5 \mu \mathrm{M}$ BCES showed a depressed ability to correct mismatched bases in the DNA and Schaaper et al (1983) have shown that the presence of apurinic sites in DNA leads to the insertion of noncomplementary bases in the nucleic acid. The other pussibility is that the repair process is error-free (Maher and McCormick, 1976, 1984; Witkin, 1975) but a metabolic abnormality has been imposed by BCES in the exposed cell. Papirmeister $e t$ al. (1985) have proposed that a drastic decrease in the level of $\mathrm{NAD}^{+}$is responsible for the death of cells exposed to BCES. Gross et al. (1985) (also cf. Smith et al., 1990) have demonstrated a decrease of $10 \%$ in the concentration of $\mathrm{NAD}^{+}$in human keratinocytes exposed to $10 \mu \mathrm{M}$ BCES. Further work will be necessary to ascertain the validity of either of these explanations for the residual toxicity in cxposed cells whose nucleoid sediments normally.

\section{REFERENCES}

ABLER, A. S., AND BERNSTEIN, I. A. (1984). Low MW factors extracted from the epidermis inhibit the incorporation of ${ }^{3} \mathrm{H} T d \mathrm{R}$ by primary keratinocytes in cultures. J. Cell Biol. 99, 389. [Abstract]

ALDENHOFF. P.. AND SPERLING. K. (1984). Simultaneous demonstration of $U V$-type and ionizing radiation-type repair by the nucleoid sedimentation technique. Mutat Res. 131, 137-142.

ALEXANDER, P. (1969). Comparison of the mode of action by which alkylating agents and ionizing radiations kill mammalian cells. N.Y. Acad. Sci. Ann. 163, 652-675.

Bernstam, L. I., Vaughan, F. I... and Bfrnstein. I. A. (1986). Keratinocytes grown at the air-liquid interface. In Vitro Cell. Dev. Biol. 22, 695-705.

Brabec, R. K., Peters, B. P., Bernstein, I. A., Gray, R. H., AND GoldosTEIN, I. J. (1980). Differential lectin binding to cellular membranes in the epidermis of the newborn rat. Proc. Natl. Acad. Sci. USA 77, 477-479.

BRENNAN, J. K., MACKY, J., ROBERT, G., AND LiChTMAN, M. A. (1975). Improved methods for reducing calcium and magnesium concentrations in tissue culture me- 
dium: Application to studies of lymphoblast proliferation in vitro. In Vitro 11, 354-360.

Brown, R., KU, W. W., AND BERnSTEIN. I. A. (1987). Changes in lectin binding by differentiating cutaneous keratinocytes from the newborn rat. $J$. Invest. Dermatol. 88, 719-726.

Charles, W. C., and Cleaver, J. E. (1982). Comparison of nucleoid and alkaline sucrose gradients in the analysis of inhibitors of DNA repair in human fibroblasts. Biochem. Biophys. Res Commun. 107, 250-257.

Cleaver, J. E. (1978). DNA repair and its coupling to DNA replication in eukaryotic cells. Biochim. Biophys. Acta 516, 489-516.

COOK, P. R., AND BRAzELL, I. A. (1976a). Conformational constraints in nuclear DNA. J. Cell Sci. 22, 287.

COOK, P. R., AND BRAZELL, I. A. (1976b). Detection of single strand breaks in nuclear DNA. Nature 26.3, 679682.

COOK, P. R., BRazell, I. A., AND Jost, E. (1976). Characterization of nuclear structures containing supercoiled DNA. J. Cell Sci. 22, 303-324.

Crathorn, A. R., AND Roberts, J. J. (1965). Reactions of cultured mammalian cells of varying radiosensitivities with the radiomimetic alkylating agent, mustard gas. $J$. Prog. Biochem. Pharmacol. 1, 320-326.

FAN, L., AND BERNSTEIN, I. A. (1991). Effect of bis- $(\beta$ chlorethyl) sulfide (BCES) on base mismatch repair of DNA in monkey kidney cells. Toxicol. Appl. Pharmacol. 111, 233-241.

Fox, M., AND SCOTT, D. (1980). The genetic toxicology of nitrogen and sulfur mustard. Mutat. Res. 75, 131168.

Friedberg. E. C. (1985). DN.4 Repair. Freeman. New York.

GICHNER, T., AND VEleminSKY, J. (1982). Genetic effects of $N$-methyl- $N^{\prime}$-nitro- $N^{\prime}$-nitrosoguanidine and its homologs. Mutat. Res. 99, 129-242.

Gross, C. L., Meier, H. L., PAPIRMeister, B., Brinkley, F. B., AND JOHNSON, J. B. (1985). Sulfur mustard lowers nicotinamide adenine dinucleotide concentrations in human skin grafted to athymic mice. Toxicol. Appl. Pharmacol. 81, 85-90.

HENNings, H., AND HOLBROOK, K. (1983). Calcium regulation of cell-cell contact and differentiation of epidermal cells in culture. Exp. Cell Res. 143, 127-142.

Hennings, H., Michael, D., Cheng, C., Steinert, P., Holbrook, K., AND YuSPA, S. H. (1980). Calcium regulation of growth and differentiation of mouse epidermal cells in culture. Cell 19, 245-254.

HolmQUisT, L. (1982). Surface modification of Beckman Ultraclear centrifuge tubes for density gradient centrifugation of lipoproteins. J. Lipid Res. 23, 1249-1250.

Ku, W. W.. AND BERNSTEIN, I. A. (1988a). Lectin binding as a probe of proliferative and differentiative phases of primary monolayer cultures of cutaneous keratinocytes. Exp. Cell Res. 175, 298-316.

Ku, W. W., AND BERNSTEIN. I. A. (1988b). Bis-( $\beta$-chlo- roethyl) sulfide (BCES)-induced changes in epidermal cell homeostasis in vitro. Toxicol. Appl. Pharmacol. 95, 397-411.

LAWLEY, P. D., AND BRoOKES, P. (1965). Molecular mechanism of the cytotoxic action of difunctional alkylating agents and of resistance to this action. Nature 206, 480-483.

Lillie, J. H., MaCCALlum, K. D., AND JEPSEN, A. (1980). Fine structure of subcultivated stratified squamous epithelium grown on collagen rafts. Exp. Cell Res. 125 , 153-165.

LindHAL, T. (1982). DNA repair enzymes. Annu. Rev. Biochem. 51, 61-87.

MaHtK, V. M., AND MCCoRmick, J. J. (1976). Effect of DNA repair on cytotoxicity and mutagenesis of $\mathrm{UV}$. irradiation and chemical carcinogens in normal and xeroderma pigmentosum cells. In Biology of Radiation Carcinogenesis. (J. M. Yuhas, R. W. Tennant, and J. D. Regan, Eds.), p. 169. Raven Press, New York.

MAHER, V. M., AND MCCORMICK, J. J. (1984). Role of DNA lesions and excision repair in carcinogen-induced mutagenesis and transformation in human cells. In Biochemical Basis of Chemical Carcinogenesis. $(\mathbf{H}$. Greim, R. Jung, M. Kramer, H. Marquardt, and F. Oesch, Eds.). Raven Press, New York.

MatTern, M. R., PAONE, R. F., AND DAY, R. S. III (1982). Eukaryotic DNA repair is blocked at different steps by inhibitors of DNA topoisomerases and of DNA polymerases alpha and beta. Biochim. Biophys. Acta 697, 6-13.

PAPIRMEISTER, B., AND DAvisON, C. L. (1965). Unbalanced growth and latent killing of Escherichia roli following exposure to sulfur mustard. Biochin. Biophys. Acia 103, 70-92.

Papirmeister, B., Feister. A. J.. Robinson. S. I.. AND FORD, R. D. (1991). Medical Defense Against Mustard Gas: Toxic Mechanisms and Pharmacological Implications. pp. 91-93. CRC Press, Boca Raton, FL.

Papirmeister, B., Gross, C. L., Meier, H. L., Petrali, F. P., AND JoHnSON, J. P. (1985). Molecular basis for mustard-induced vesication. Fundam. Appl. Toxicol. 5, S134-S149.

Ribeiro, P. L. (1988). The Repair of Bis-(beta-chloroethyl)sulfide (BCES)-Induced Alkylation Damage and Iis Possible Role in the Survival of Exposed Primary' Monolayer Cultures of Rat Culaneous Keratinocytes. Thesis, The University of Michigan, Ann Arbor.

ROBERTS. J. J. (1978). Repair of DNA modified by cytotoxic, mutagenic and carcinogenic chemicals. $A d v$. Radiat. Biol. 7, 211-436.

Roberts, J. J.. Brent, T. P., and Crathorn, A. R. (1968). The mechanism of cytotoxic action of alkylating agents on mammalian cells. In Interactions of Drugs and Subcellular Components in Animal Cells (P. N. Campbell, Ed.), pp. 5-27. Churchill, London, England. Robison, S. H., Cantoni. O., And Costa, M. (1984). 
A nalysis of metal-induced DNA lesions and DNA repair replication in mammalian cells. Mutat. Res. 131, 173181.

Romagna, F., KulKarni, M. S., AND ANDERSON, M. W. (1985). Detection of repair of chemical-induced DNA damage in vivo by the nucleoid sedimentation assay. Biochem. Biophys. Res. Commun. 127, 56-62.

Ross. W. C. J. (1962). Biological Alkylating Agents. Butterworths. London.

SCAVARElli-Karantsavelos, R. M. (1989). Comparative Effect of Bis-(beta-chlorethyl) sulfide on Basal and Differentiated Keratinocytes. Thesis, The University of Michigan. Ann Arbor.

Scavarfil.J-Karantsavelos. R. M., Zaman-Saroya, S., Vaughan, F. L., AND Bernstein, I. A. (1990). Pseudoepidermis. constructed in vitro, for use in toxicological and pharmacological studies. Skin Pharmacol. 3, 115-125.

SchaAPER, R. M., Kunkel, T. A., AND LOEB, L. A. (1983). Infidelity of DNA synthesis associated with bypass of apurinic sites. Proc. Natl. Acad. Sci. USA 80, $487-491$.

Setaro, R.. And Morley, C. D. G. (1976). A modified fluorometric method for the determination of microgram quantities of DNA from cell and tissue cultures. Anal. Biochem. 71, 313-317.

SinCLAIR, D, C. (1949). The clinical reaction of the skin to mustard gas vapor. Br. J. Dermatol. 611, 113-125.

Smith, W. J., Gross, C. L. Chan. P., and Meier, H. L. (1990). The use of human epidermal keratinocytes in culture as a model for studying the biochemical mechanisms of sulfur mustard toxicity. Cell Biol. Tox icol. 6, 285-291.

SORSCHER, D. H., AND CONOLLY, R. B. (1989). Pretreatment of primary cutaneous epidermal keratinocyte cultures with a low concentration of MNNG: Effect on DNA cross-linking measured in situ after challenge with bis-(2-chloroethyl)sulfide. J. Toxicol. Environ. Health 27, 367-379.
VAUGHAN, F. L., AND BERNSTEIN, I. A. (1976). Molecular aspects of control in epidermal differentiation. Mol. Cell. Biochem. 12,171-179.

Vaughan, F. L., Gray, R. H., and Bernstein, I. A. (1986). Growth and differentiation of primary rat keratinocytes on synthetic membranes, In Vitro Cell. Dev. Biol. 22, 141-149.

Vaughan, F. L., Kass, L., and Uzman, J. A. (1981). Requirement of hydrocortisone and insulin for extended proliferation and passage of rat keratinocytes. In Vitro Cell. Dev. Biol. 17, 941-946.

Vaughan, F. L., Zaman, S., SCavarelli, R. M., and BERNSTEIN, I. A. (1988). Macromolecular metabolism of a differentiated rat keratinocyte culture system following exposure to sulfur mustard. J. Toxicol. Environ. Health 23, 507-518.

Vogt, F., Dannenberg, A. M., Schofield, B. H., Hynes, N. A., and Papirmeister, B. (1984). Pathogenesis of skin lesions caused by sulfur mustard. Fundam. Appl. Toxicol. 4, 71-83.

WALKER, I. G. (1966). Sulfur mustard reaction with Lcells treated with 5-fluorodeoxyuridine. Science 151, 99101.

WALKER, I. G., AND THATCHER, C. J. (1968). Studies on the lethal effects of sulfur mustard on dividing mammalian cells. Radiat. Res. 34, 110-127.

Warthin, A. S., AND Weller, C. V. (1919). The Medical Aspects of Mustard Gas Poisoning. Mosby, St. Louis.

WHEELER, G. P. (1962). Studies related to the mechanisms of action of cytotoxic alkylating agents: A review. Can. Res. 22, 651-686.

WITKIN, E. M. (1975). In Molecular Mechanisms for Repair of DNA. (P. C. Hanawalt and R. B. Setlow, Eds.), Part A, p. 347. Plenum, New York.

YEW, F. F-H., AND JoHnson, R. T. (1979). Ultravioletinduced DNA excision repair in human $B$ and $T$ lymphocytes. II. Effect of inhibitors and DNA precursors. Biochim. Biophys. Acta 562, 240-251. 